\title{
PENINGKATAN KEMAMPUAN GURU DALAM MEMBUAT E-LEARNING SEBAGAI MEDIA PEMBELAJARAN BERBASIS TEKNOLOGI INFORMASI DI SMA NEGERI 1 SUBAH
}

\author{
Oman Somantri $^{1 *}$, Taufiq Abidin ${ }^{1}$, Dega Surono Wibowo ${ }^{1}$, Slamet Wiyono ${ }^{1}$ \\ ${ }^{1}$ Jurusan Teknik Informatika, Politeknik Harapan Bersama Tegal, Tegal \\ *Penulis Korespodensi: oman.somantri@poltektegal.ac.id
}

\begin{abstract}
Abstrak
Internet learning adalah sebuah proses pembelajaran yang berbasis elektronik yang digunakan sebagai media pembelajaran yang dilaksanakan oleh setiap lembaga pendidikan. Dalam rangka pengembangan proses pembelajaran yang dilaksanakan di SMAN 1 Subah, maka konsep internet learning diterapkan. Metode kegiatan yang digunakan untuk mencapai tujuan dari kegiatan pengabdian masyarakat ini adalah dengan metode ceramah dan praktek dengan menggunakan media sosial Edmodo dimana semua peserta pelatihan setelah mendapatkan materi yang disampaikan kemudian mempraktekan apa yang sudah diberikan implementasinya. Dari kegiatan pengabdian pada masyarakat ini dapat disimpulkan pengetahuan dan pemahaman akan penerapan Internet learning melalui media sosial yang diberikan kepada para Guru SMAN 1 Subah yang ikut pelatihan tersebut dapat memberikan pemahaman baru mengenai terdapatnya media pembelajaran alternatif yang bisa digunakan dalam proses pembelajaran di kelas, pada akhirnya sekolah SMAN 1 Subah mempunyai suatu metode konsep pembelajaran baru yang dapat dijadikan alternatif pembelajaran.
\end{abstract}

Kata kunci: Internet Learning, Edmodo, Guru

\begin{abstract}
Internet learning is an electronic learning process that is used as a learning medium implemented by every educational institution. In order to develop the learning process that is implemented in SMAN 1 Subah, the concept of internet learning is applied. The method of activities used to achieve the objectives of community service activities is by lecture method and practice by using social media Edmodo where all the trainees getting the material with is submitted then practice it. From the dedication activities in this community, it can be concluded that the knowledge and understanding of the application of Internet learning through social media given to the teachers of SMAN 1 Subah who is that participate in this training can provide new understanding about the existence of alternative learning media that can be used in the learning process in the classroom, finally SMAN 1 Subah has a new learning concept method that can be used as an alternative learning.
\end{abstract}

Keywords: Internet Learning, edmodo, Teacher

\section{PENDAHULUAN}

Internet learning adalah sebuah proses pembelajaran yang berbasis elektronik (Febrian, 2004). Salah satu media yang digunakan adalah jaringan komputer. Dengan dikembangkannya di jaringan komputer memungkinkan untuk dikembangkan dalam bentuk berbasis web, sehingga kemudian dikembangkan ke jaringan komputer yang lebih luas yaitu internet (Suyanto, 2005). Penyajian $e$ learning berbasis web ini bisa menjadi lebih interaktif (Arifin, 2009; Yazdi, 2012). Sistem e-learning ini tidak memiliki batasan akses, inilah yang memungkinkan pembelajaran bisa dilakukan lebih banyak waktu (Lestariningsih, 2016). e-learning dapat diartikan pula sebagai suatu sistem dalam pembelajaran yang mengacu pada penggunaan teknologi informasi yang dapat meningkatkan pengetahuan dan keterampilan dengan karakteristik- karakteristik seperti memanfaatkan jasa teknologi, memanfatkan keunggulan komputer, menggunakan bahan ajar yang bersifat mandiri, dan memanfaatkan jadwal belajar yang dapat dilihat pada komputer, serta memberikan fasilitas yang dapat diakses oleh pengajar dan peserta didik/mahasiswa secara pribadi.

Manfaat e-learning (Yasa, 2017) terdiri atas 4 hal, yaitu: (1) Meningkatkan kadar interaksi pembelajaran antara peserta didik dengan guru atau instruktur (enhance interactivity); (2) Memungkinkan terjadinya interaksi pembelajaran dari mana dan kapan saja (time and place flexibility); (2) Menjangkau peserta didik dalam cakupan yang luas (potential to reach a global audience); (4) Mempermudah penyempurnaan dan penyimpanan materi pembelajaran (easy updating of content as well as archivable capabilities). e-learning lebih tepat ditujukan sebagai usaha untuk membuat sebuah 
transformasi proses belajar mengajar yang ada di sekolah/universitas ke dalam bentuk digital yang dijembatani oleh teknologi internet (Purbo \& Hartanto, 2002).

Implementasi e-learning ini telah banyak yang mengimplementasikannya, seperti yang dilakukan oleh Mandoyo, (2017) membangun Pembelajaran Berbasis Web (E-Learning) bagi Guru Sekolah Dasar Pinggiran Kecamatan Muara Bangkahulu Kota Bengkulu. Wijaya (2012) melakukan Pengembangan model pembelajaran e-learning berbasis web dengan prinsip e-Pedagogy dalam meningkatkan hasil belajar. Disamping itu, media blog pun digunakan oleh (Zulkardi, Z., 2010) dengan melakukan pengembangan blog support untuk membantu siswa dan guru matematika Indonesia belajar pendidikan matematika realistic Indonesia (PMRI).

Salah satu aplikasi e-learning yang dapat digunakan adalah Edmodo. Edmodo merupakan layanan berbasis internet yang disediakan sebagai sebuah jaringan belajar yang memungkinkn pengajar berbagi konten pembelajaran, memberikan kuis dn tugas, serta berkomunikasi dengan student, pengajar yang lain serta orang tua student (Holland \& Muilenburg, 2011).

SMA N 1 Subah merupakan salah satu sekolah menengah atas negeri di kabupaten Batang. Sekolah Menengah Atas yang terletak di Jalan Raya Jatisari Kecamatan Subah kabupaten Batang ini memiliki 3 Angkatan yang terdiri dari 21 kelas. Dimana Kelas X terdiri dari 7 kelas, kelas XI dan XII terdiri dari 2 kelas jurusan Bahasa Indonesia, 2 Kelas IPS dan 3 Kelas IPA. Jumlah siswa aktif di SMA N 1 Subah \pm 850 siswa dengan jumlah guru \pm 35 orang dan karyawan \pm 15 orang. Infrastruktur teknologi informasi yang terdapat pada SMA N 1 Subah sudah cukup baik, ini terbukti dari beberapa ruang kelas yang telah menggunakan LCD Proyektor, terdapat finger print untuk absensi guru dan karyawan, terdapat laboratorium komputer, laboratorium bahasa, dan perpustakkan. Beberapa guru SMA N 1 Subah sudah menggunakan laptop dalam pengajarannya dan SMA N 1 Subah juga memiliki website dalam penyampaian informasi.

Namun, kegiatan belajar dan mengajar yang dilaksanakan di SMA N 1 Subah hanya menggunakan metode tatap muka di kelas. Materi ajar sering di upload, tetapi masih menggunakan website dan hanya untuk upload materi saja. Apabila hanya mengandalkan metode yang demikian, maka jelas terdapat beberapa kendala yang dihadapi, diantaranya: ketergantungan terhadap kehadiran guru, pelaksanaan pembelajaran juga tergantung pada sebuah ruangan kelas, ini jelas kurang efisien dari sisi sarana prasarana pembelajaran. Hal tersebut juga bertolak belakang dengan infrastruktur teknologi informasi yang dimiliki oleh SMA N 1 Subah. Bertolak pada keadaan tersebut, perlu kiranya sebuah solusi yang dapat mengatasi permasalahan tersebut guna memanfaatkan teknologi dalam melaksanakan proses kegiatan belajar mengajar.
Solusi yang dapat dilakukan untuk mengatasi permasalahan yang ada, tim pelaksana kegiatan PKM telah bersepakat dengan mitra yaitu SMAN 1 Subah yaitu dengan cara memberikan pelatihan kepada guru SMA N 1 Subah untuk memanfaatkan teknologi informasi dalam melaksanakan kegiatan belajar mengajar yakni menggunakan internet learning. Media yang digunakan adalah aplikasi e-learning Edmodo. Hasil luaran yang diharapkan pada kegiatan PKM ini adalah Guru dapat memiliki kemampuan untuk dapat membuat e-learning yang nantinya diterapkan pada proses pembelajaran dikelas.

\section{METODE}

\subsection{Tahapan Metode Kegiatan}

Untuk mengatasi permasalahan yang dihadapi oleh SMAN 1 Subah, maka metode yang digunakan tahapan-tahapannya adalah sebagai berikut:

\section{1) Analisis Situasi dan Survei}

Tahapan ini merupakan tahapan pertama yang dilakukan sebelum kegiatan PK dilakukan. Pada tahapan ini dilakukan survey kepada mitra yang dituju yaitu SMAN 1 Subah, setelah itu dilakukan analisis terkait dengan situasi yang sedang berjalan di tempat mitra. Pada tahapan analisis situasi ditemukan beberapa permasalahan yang dihadapi oleh mitra.

\section{2) Penentuan Permasalahan prioritas}

Berdasarkan kesepakatan bersama antara tim PKM dan mitra ditentuknalah permasalahan prioritas yang harus segera dicarikan solusinya sehingga pada tahapan ini permasalahan utama sudah ditentukan untuk diselesaikan.

\section{3) Solusi Yang diusulkan}

Tahapan ini adalah penentuan solusi yang disusulkan oleh tim pelaksana PKM kepada mitra, sesuai dengan kesepakatan maka solusi yang diusulkan dijalankan sesuai dengan konsep dan metode yang telah ditentukan oleh tim pelaksanana PKM dan disetujui oleh mitra.

\section{4) Luaran (Outcome)}

Pada solusi yang telah ditentukan, luararan yang diharapkan pada kegiatan PKM ini adalah Guru SMAN 1 Subah memiliki kemampuan utnuk dapat membuat media pembeljaran dengan menggunakan elearning sehingga dapat diterapkan pada proses pembelajaran di kelas kepada sisiwa.

\section{5) Evaluasi dan Pendampingan}

Untuk mengukur sejauhmana tingkat keberhasilan dari kegiatn PKM yang telah dilaksanakan maka dilakukan evaluai dan pendampingan. Tahapan ini dilakukan untuk men-sinkronkan antara tujuan dan harapan dari kegiatan PKM ini agar sesuai dengan outcome atau luaran yang telah ditentukan. Evaluasi dilakukan dengan cara memberikan peserta pelatihan soal pre-test sebelum pelatihan 
dilaksanakan, setelah itu diberikan kembali soal post-test setelah kegiatan dilaksanakan.

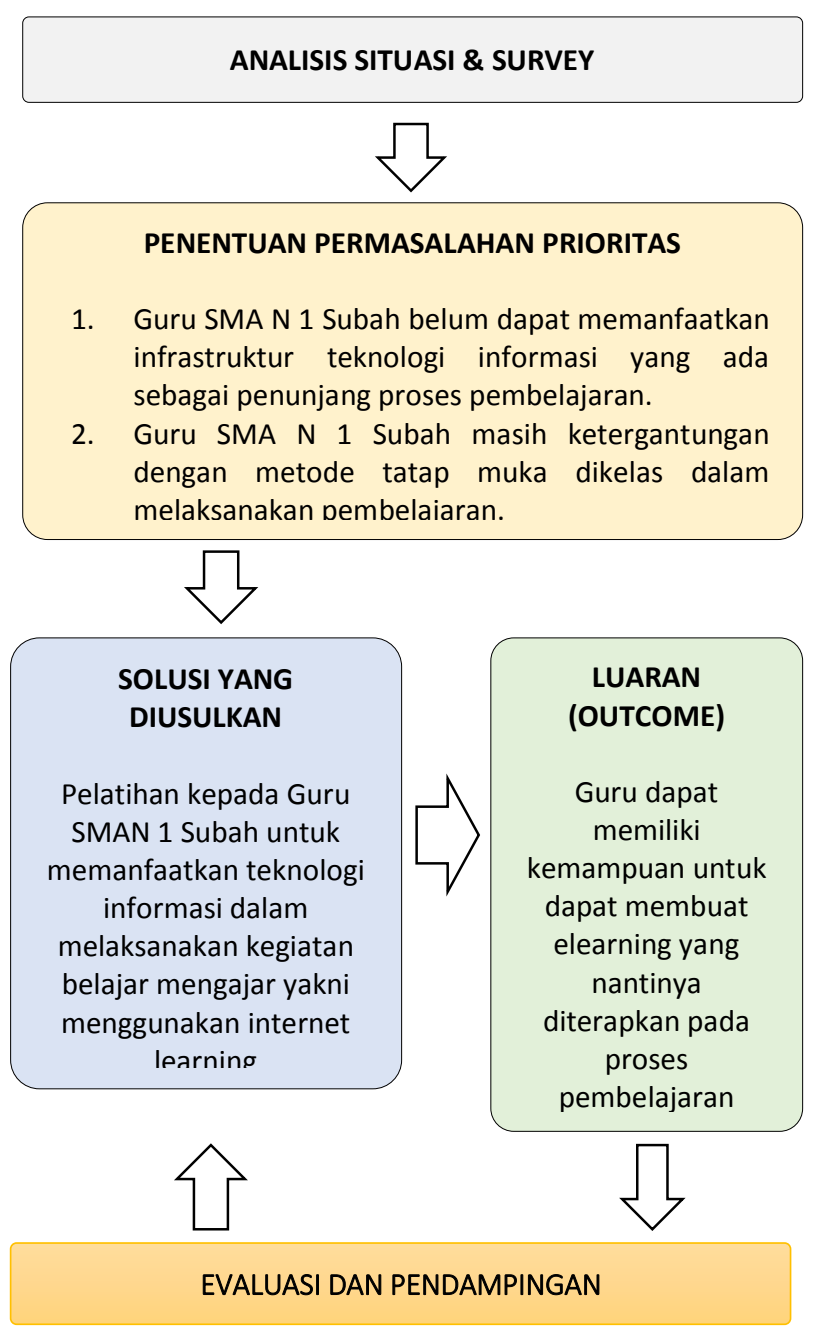

Gambar 1. Tahapan solusi metode yang diusulkan

Pada gambar 1 diperlihatkan tahapan-tahapan metode yang diusulkan pada kegiatan PKM yang dilaksanakan sebagai solusi permasalahan yang dihadapi oleh mitra,

\subsection{Pendekatan Program}

Pendekatan yang digunakan pada kegiatan pelatihan ini (Santoso, 2010) adalah:

a) Pendekatan partisipatoris, dimana pada kegiatan ini para peserta kegiatan diikutkan pada tahapan proses pelatihan mulai dari awal sampai dengan akhir kegiatan.

b) Pendekatan andragogi, dimana fasilitator mengakui kemampuan, keunggulan dan pengalaman peserta pelatihan. Pada pelatihan ini fasilitator lebih banyak untuk mengungkap pengalaman dan kemampuan dari peserta pelatihan untuk dapat di-sharing kepada peserta alain, sehingga peserta pelatihan lebih banyak berkontribusi.

c) Learning by doing, pada pelatihan peserta pelatihan akan lebih banyak praktek dibandingkan dengan teoritis sehingga pemaparan materi yang disampaikan lebih mudah untuk dimengerti.

d) Pendekatan konstektual, dimana pada pelatihan ini materi yang disampaikan disesuaikan dengan keadaan permasalahan yang terdapat di tempat mitra peserta pelatihann berada sehingga studi kasus yang diberikan sesuai dengan real kenyataan yang terjadi di tempat mitra.

\subsection{Langkah Kegiatan}

Metode yang diusulkan sebagai solusi dari permasalahan tersebut yaitu berupa pelatihan. Adapun langkah-langkah yang dilakukan pada pelaksanaan pelatihan tersebut diantaranya:

\section{a. Persiapan}

Persiapan dilakukan untuk memperoleh sebuah kesepakatan anatara tim pelaksana kegiatan dengan mitra terkait dengan permasalahan dan solusi yang akan dilakukan dalam hal ini adalah Kepala SMAN 1 Subah. Pada tahapan ini dilakukan persiapan terkait dengan pelatihan mulai dari pemberitahuan kepada Guru, persiapan tempat pelatihan, dan waktu pelatihan serta materi yang akan diberikan.

b. Pelaksanaan

Pelaksanaan kegiatan pelatihan dilaksanakan di ruang lab komputer SMAN 1 Subah, dengan jumlah peserta pelatihan 16 Guru dan materi disampaikan oleh tim pelaksanaan PKM yaitu Dosen prodi D4 Teknik Informatika Politeknik Harapan Bersama dibantu oleh 5 orang mahasiswa sebagai pendamping pelatihan.

c. Evaluasi

Evaluasi dilaksanakan dengan menggunakan pretest dan post-test untuk melihat sejauhmana tingkat keberhasilan dari kegiatan pelatihan yang dilaksanakan.

\subsection{Lokasi dan Pelaksanaan Pelatihan}

Pada pelaksanaan kegiatan ini khalayak sasaran pada kegiatan pengabdian ini adalah Guru dan Staf Pengajar SMAN 1 Subah yang terdiri dari para Guru pengajar mulai dari kelas 10, 11 dan 12 dari berbagai jurusan sebanyk 16 orang peserta kegiatan. Kegiatan dilaksanakan selama 2 hari pada bulan April 2016 di laboratorium komputer SMAN 1 Subah.

Alat yang dijadikan sebagai media pembelajaran adalah aplikasi Edmodo. Edmodo sendiri merupakan sebuah aplikasi berbasis internet yang mudah untuk digunakan tetapi mempunyai fitur dan fasilitas yang memungkinkan untuk digunakan sebagai media pembelajaran e-learning sehingga dengan penggunaan aplikasi ini capaian dari pelaksanaan kegiatan PKM dapat tercapat sesuai dengan yang diharapkan. Materi yang disampaikan pada pelatihan tersebut adalah materi yang disesuaikan dengan tujuan dari kegiatan PKM diantaranya adalah: (1) pengenalan konsep e-learning; dan (2) penggunaan dan Praktek Edmodo sebagai media pembelajaran. Materi yang disampaikan merupakan bagian yang tidak terpisahkan dari konsep 
e-learning itu sendiri sebagai media pembelajaran yang didalamnya terdapat Infrastruktur e-learning, Sistem dan aplikasi e-learning, dan konten e-learning (Yasa, 2017).

\section{HASIL DAN PEMBAHASAN \\ 3.1 Pelaksanaan Kegiatan}

Kegiatan pelatihan yang sudah ditentukan, dilaksanakan sesuai dengan waktu yng telah ditentukan. Dari hasil pelatihan yang telah dilakukan, para peserta kegiatan memiliki kemampuan untuk membuat e-learning sesuai dengan account yang telah dimilikinya per-orang.

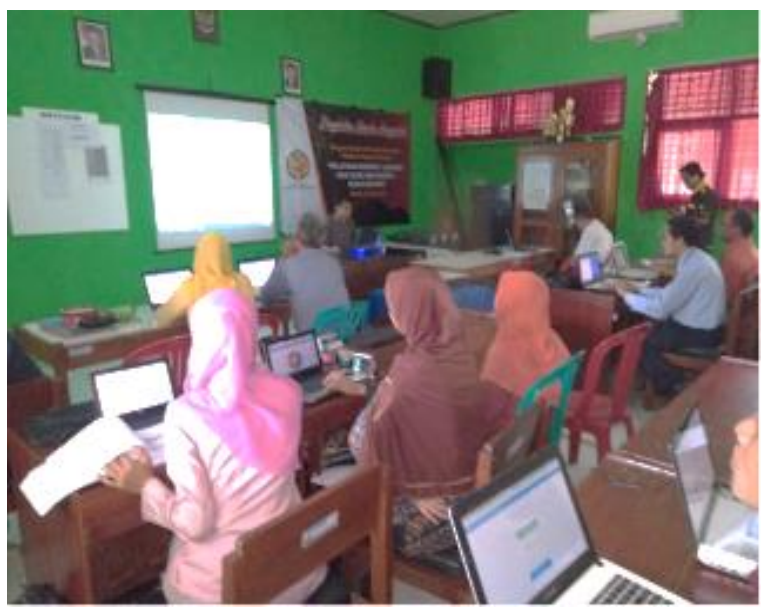

Gambar 2. Pemaparan materi pelatihan e-learning.

Pada gambar 2 diperlihatkan situasi pada saat pemamaparan materi yang disampiakan oleh fasilitator yakni tim penegabdian kepada masyarakat.

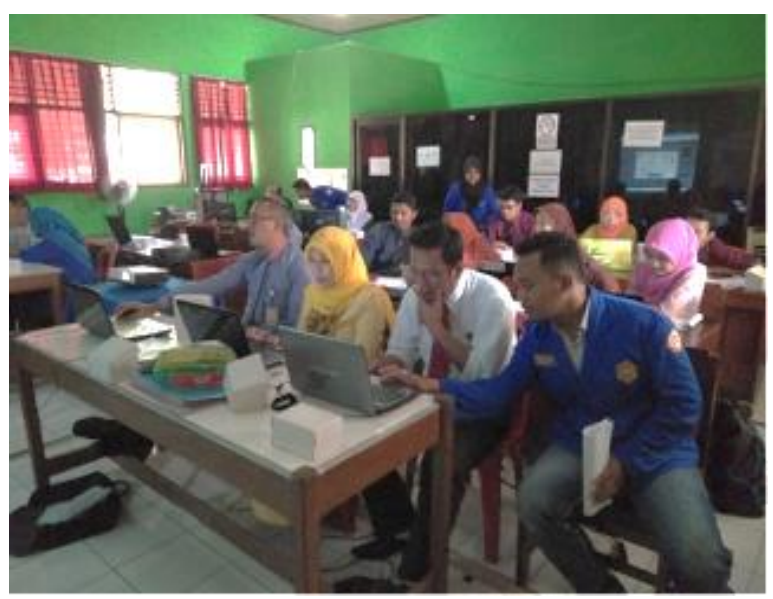

Gambar 3. Proses pendampingan oleh mahasiswa pada pelatihan

Pada pelaksanaan kegiatan PKM peranan mahasiswa diberdayakan dan diberikan tugas sebagai pendamping pada saat kegiatan pelatihan berlangsung seperti diperlihatkan pada gambar 3 .

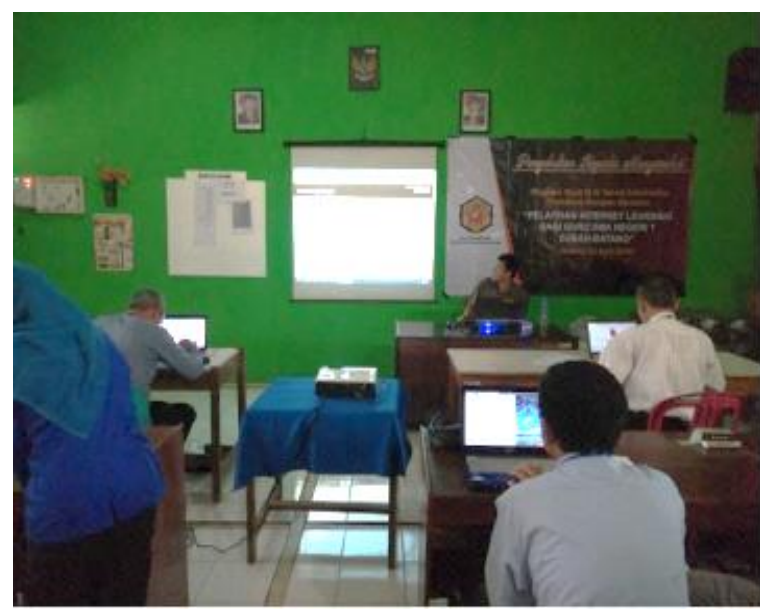

Gambar 4. Kegiatan Pelatihan di SMAN 1 Subah, 2016

Selama kegiatan berlangsung telah dihasilkan target luaran yang diharapkan. Pada tabel 2 diperlihatkan hasil dari luaran pelatihan yang telah dilakukan yaitu berupa daftar account e-learning yang dibuat oleh beberapa peserta pelatihan.

Tabel 1. Account e-learning peserta pelatihan

\begin{tabular}{|c|c|c|}
\hline No. & Nama Peserta & Account e-learning Edmodo \\
\hline 1 & Firsty Asri & $\begin{array}{l}\text { https://www.edmodo.com/prof } \\
\text { ile/firstyasri }\end{array}$ \\
\hline 2 & $\begin{array}{l}\text { Zulkham } \\
\text { Fatturrakhman }\end{array}$ & $\begin{array}{l}\text { https://www.edmodo.com/prof } \\
\text { ile/youhiruma } 2\end{array}$ \\
\hline 3 & $\begin{array}{l}\text { Murdiana } \\
\text { Dian }\end{array}$ & $\begin{array}{l}\text { https://www.edmodo.com/prof } \\
\text { ile/murdiana77 }\end{array}$ \\
\hline 4 & Pudya Saras & $\begin{array}{l}\text { https://www.edmodo.com/prof } \\
\text { ile/pudyasaras }\end{array}$ \\
\hline 5 & Tika & $\begin{array}{l}\text { https://www.edmodo.com/prof } \\
\text { ile/ibunearkaa }\end{array}$ \\
\hline 6 & Hardoko & $\begin{array}{l}\text { https://www.edmodo.com/prof } \\
\text { ile/sakhabola }\end{array}$ \\
\hline 7 & $\begin{array}{l}\text { Andhy } \\
\text { Prasetyo }\end{array}$ & $\begin{array}{l}\text { https://www.edmodo.com/prof } \\
\text { ile/bhsindones } 87\end{array}$ \\
\hline 8 & Dwi Fitriana & $\begin{array}{l}\text { https://www.edmodo.com/prof } \\
\text { ile/fitrianadw }\end{array}$ \\
\hline 9 & $\begin{array}{l}\text { Untung } \\
\text { Alfarizi }\end{array}$ & $\begin{array}{l}\text { https://www.edmodo.com/prof } \\
\text { ile/titunguntu }\end{array}$ \\
\hline 10 & Sugito & $\begin{array}{l}\text { https://www.edmodo.com/prof } \\
\text { ile/civitasmab }\end{array}$ \\
\hline
\end{tabular}

Pada gambar 5 dan 6 merupakan contoh tampilan dari interface e-learning yang telah dibuat oleh perserta pelatihan Guru SMAN 1 Subah. 


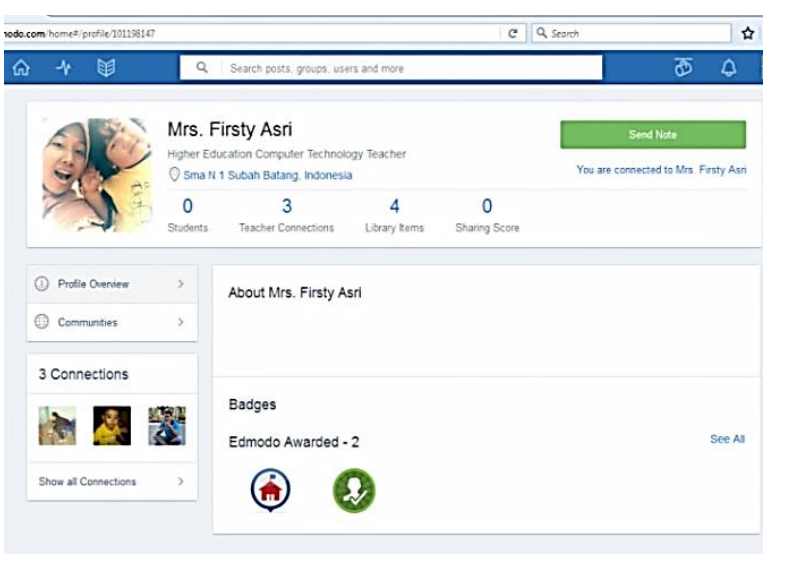

Gambar 5. Screenshoot Edmodo salah satu Guru peserta pelatihan (Oleh: Firsty Asri, S.Kom Guru SMAN 1 Subah)

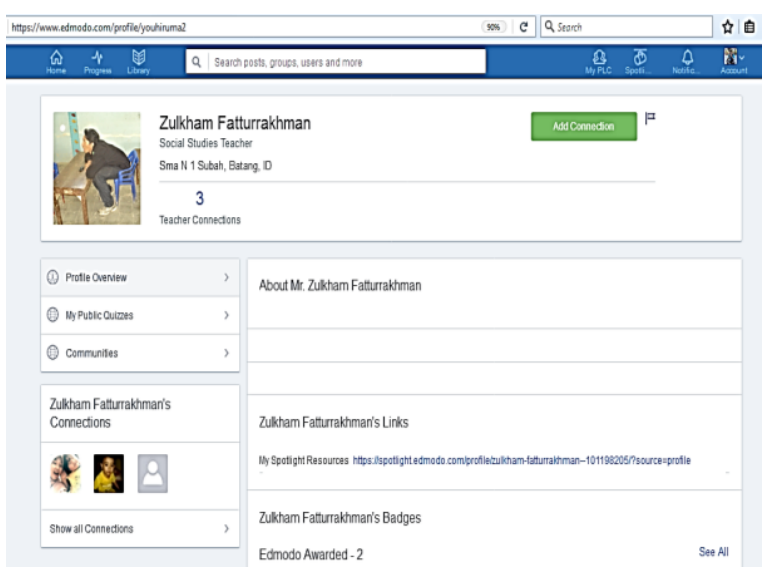

Gambar 6. Screenshoot Edmodo salah satu Guru peserta pelatihan (Oleh: Zulkham Fatturrakhman Guru SMAN 1 Subah)

\subsection{Evaluasi Hasil Pendampingan}

Evalusi dilakukan untuk melihat sejauhmana tingkat keberhasilan dari pelatihan yang dilaksanakan. Penilaian pre-test dan post-test dilakukan sebagai bagian dari metode yang dilakukan. Materi pertanyaan yang diberikan kepada peserta pelatihan adalah pertanyaan-pertanyaan yang terkait dengan pengetahuan konsep ilearning dan pengoperasian aplikasi Edmodo, dengn jumlah pertanyaan yang diberikan adalah sebanyak 20 pertanyaan.

Pada tabel 2 diperlihatkan hasil dari penilaian yang sudah dilakukan terhadap para peserta kegiatan.

Tabel 2. Hasil penilaian pre-test dan post-test peserta pelatihan

\begin{tabular}{ccccc}
\hline No. & $\begin{array}{c}\text { Kode } \\
\text { Peserta }\end{array}$ & $\begin{array}{c}\text { Nilai } \\
\text { Pre-test }\end{array}$ & $\begin{array}{c}\text { Nilai } \\
\text { post-test }\end{array}$ & $\begin{array}{c}\text { Kenaikan } \\
\text { \% }\end{array}$ \\
\hline 1 & G-01 & 40 & 85 & 112.50 \\
2 & G-02 & 30 & 70 & 133.33 \\
3 & G-03 & 50 & 80 & 60.00 \\
4 & G-04 & 70 & 90 & 28.57 \\
5 & G-05 & 40 & 60 & 50.00 \\
6 & G-06 & 65 & 80 & 23.08
\end{tabular}

\begin{tabular}{|c|c|c|c|c|}
\hline 7 & G-07 & 20 & 70 & 250.00 \\
\hline 8 & G-08 & 20 & 85 & 325.00 \\
\hline 9 & G-09 & 45 & 80 & 77.78 \\
\hline 10 & G-10 & 30 & 80 & 166.67 \\
\hline 11 & G-11 & 55 & 90 & 63.64 \\
\hline 12 & G-12 & 55 & 85 & 54.55 \\
\hline 13 & G-13 & 30 & 80 & 166.67 \\
\hline 14 & G-14 & 60 & 80 & 33.33 \\
\hline 15 & G-15 & 10 & 75 & 650.00 \\
\hline 16 & G-16 & 50 & 90 & 80.00 \\
\hline \multicolumn{2}{|c|}{ Rata-Rata } & 41.875 & 80 & 91.04 \\
\hline
\end{tabular}

Pada tabel 2, kenaikan persentasi nilai dihitung dengan cara: Besar $=($ besar kenaikan / nilai pre-test $\mathrm{X}$ $100 \%$ ) sehingga didapatkan nilai rata-rata kenaikan sekitar $90,04 \%$.

\section{KESIMPULAN}

Dari kegiatan pengabdian pada masyarakat ini terdapat berberapa yang dapat disimpulkan diantaranya: (1) Pengetahuan dan pemahaman akan penerapan Internet learning melalui media sosial yang diberikan kepada para Guru SMAN 1 Subah yang ikut pelatihan tersebut dapat memberikan pemahaman baru mengenai terdapatnya media pembelajaran alternatif yang bisa diguanakan dalam proses pembelajaran di kelas; (2) Sekolah SMAN 1 Subah akhirnya mempunyai suatu metode konsep pembelajaran baru yang dapat dijadikan alternative pembelajaran. Mengingat besarnya manfaat kegiatan pengabdian pada masyarakat ini, maka saran yang dapat dipertimbangkan adalah perlu adanya pelatihan yang berkelanjutan khusus bagi Guru SMAN 1 Subah sehingga dapat lebih memperdalam kembali mengenai internet learning khususnya dalam praktek penggunaannya.

\section{UCAPAN TERIMA KASIH}

Ucapan terima kasih ditujukan kepada Institusi Politeknik Harapan Bersama Tegal yang telah memberikan dana pengabdian kepada masyarakat untuk dana anggaran tahun 2016 serta kepada mitra dan pihak-pihak yang membantu pelaksanaan kegiatan pengabdian Kepada Masyarakat yang telah dilaksanakan.

\section{DAFTAR PUSTAKA}

Arifin, Z. (2009). Evaluasi pembelajaran. Bandung: Remaja Rosdakarya, 77.

Febrian, J. (2004). Kamus komputer dan teknologi informasi. Jakarta: Penerbit Informatika.

Hartanto, A. A., \& Purbo, O. W. (2002). Buku pintar internet teknologi e-learning berbasis PHP dan MySQL. Jakarta: Penerbit PT Elex Media Komputindo Kelompok Gramedia.

Lestariningsih, D. (2016). The Development Of ELearning Social Media Base To The Study Of Group Dynamic In Sttiaa Pacet Mojokerto. Jurnal TEKPEN, 1(2). 
Mandoyo, B. S. S. (2017). Membangun Pembelajaran Berbasis Web (E-Learning) Bagi Guru Sekolah Dasar Pinggiran Kecamatan Muara Bangkahulu Kota Bengkulu. Jurnal Pengabdian Masyarakat Indonesia, 1(1).

Santoso, B. (2010). Skema dan Mekanisme Pelatihan: Panduan Penyelenggaraan Pelatihan. Yayasan Terumbu Karang Indonesia.

Suyanto, A. H. (2005). Pengenalan e-learning. Diakses: April 2016

Wijaya, M. (2012). Pengembangan model pembelajaran e-learning berbasis web dengan prinsip e-Pedagogy dalam meningkatkan hasil belajar. Jurnal Pendidikan Penabur, 11(19), 20-27.

Yasa, A. D. (2017). Creative Writing Class Iv After Taught The Scientific Approach. ADRI International Journal Of Education Technology, 1(1).

Yazdi, M. (2012, May). E-learning Sebagai Media Pembelajaran Interaktif Berbasis Teknologi Informasi. In FORISTEK: Forum Teknik Elektro dan Teknologi Informasi (Vol. 2, No. 1).

Zulkardi, Z., Putri, I., \& Ilma, R. (2010). Pengembangan blog support untuk membantu siswa dan guru matematika Indonesia belajar pendidikan matematika realistic Indonesia (PMRI). Jurnal Inovasi Perekayasa Pendidikan (JIPP), 2(1), 1-24.

Holland, C., \& Muilenburg, L. (2011). Supporting student collaboration: Edmodo in the classroom. In Society for Information Technology \& Teacher Education International Conference (pp. 3232-3236). Association for the Advancement of Computing in Education (AACE). 